\title{
The Use of Dam Environmental Vulnerability Index (DEVI) for Assessing Vulnerability of Bengawan Solo Watershed, Indonesia
}

\section{RR Mashita Fauzia Hannum, I Putu Santikayasa, Muh. Taufik}

Department of Geophysics and Meteorology, Faculty of Mathematics and Natural Sciences, IPB University, Dramaga Campus, Bogor, Indonesia 16680

\section{ARTICLE INFO}

\section{Received}

19 October 2020

Revised

23 November 2020

\section{Accepted for Publication}

25 November 2020

\section{Published}

9 Desember 2020

doi: 10.29244/j.agromet.34.2.110-120

\section{Correspondence:}

Muh. Taufik

Department of Geophysics and

Meteorology, Faculty of Mathematics and Natural Sciences, IPB University, Dramaga Campus, Bogor, Indonesia 16680

Email: mtaufik@apps.ipb.ac.id

This is an open-access article distributed under the CC BY License. (c) 2020 The Authors. Agromet.

\begin{abstract}
A B S T R A C T
Bengawan Solo is the longest river in Java, but current conditions show that its watershed is in a critical condition. Deforestation was very intensive in the last three decades that contributed to degradation of the watershed. Other factor contributing to the degradation is dam construction. However, our knowledge on the impact of dam construction on the environment and its vulnerability is poorly understood. Here, we assessed vulnerability of the watershed based on physical properties such as existing dams, morphodynamic activities, and deforested area. The study aims to identify the vulnerability of the Bengawan Solo watershed based on dam environmental vulnerability index (DEVI) approach, and to analyse the dominant variable contributing to DEVI. For calculating DEVI, several data were needed including land cover, rainfall, stream water stage, soil type, stream network, and dams. The results showed that Bengawan Solo watershed had moderate to high vulnerability (60\%). Moderate level was identified for Madiun and Wonogiri sub-watershed, while high level was in Cepu and Babat sub-watershed. Our findings revealed that morpho-dynamic activities as represented by sediment rate and stream water stage had contributed to the high DEVI value as in Cepu and Babat sub-watershed. Further, influence of dams in this research was not dominant implying that any improvement to the DEVI approach remains research challenges. The improvement of the approach is expected to better identify the impact of dam construction on environment, situated in other regions than Amazon, where it was firstly developed.
\end{abstract}

KEYWORDS

deforestation, morpho-dynamic, sediment yield, sensitivity, water stage

\section{INTRODUCTION}

Watershed is an integrated area comprising land, river, and its tributaries, which collects, stores, and streams rainfall water to lake or sea. The existence watershed has an important role for society such as providing water for daily life, irrigation, and industries. One of important watersheds in Java is Bengawan Solo, the longest river, which flowing water from central to eastern Java. Bengawan Solo plays a substantial role to socio-economic activities in the region (Wijayanti et al., 2016). The watershed covers area of $15,836 \mathrm{~km}^{2}$, which occupies 20 districts in Central Java and East Java. In the last three decades, land use change has caused severe land degradation (Marhaento et al., 2017) that led
Bengawan Solo to be one critical watershed in Indonesia. For example, high sedimentation rate in the downstream was reported due to land use change (Soemitro et al., 2020), volcanic eruption (Hidayat et al., 2018), and morphology change such as erosion (Maulana et al., 2019). In respond to Bengawan Solo condition, Indonesian government in 2009 had categorized Bengawan Solo as a critical watershed that should be restored (Ministry of Forestry, 2009).

Current knowledge reveals that degradation in watershed is associated with an increased population and urbanization (Dasanto, 2006; Irsyad et al., 2011; Li et al., 2020; Weil et al., 2019; Widyastuti and Taufik, 2019). In many countries, dam construction was pur- 
posed to fulfill water needs by society such as Three Gorges Reservoir in China (Tang et al., 2018) and Tarbela in Pakistan (Naz et al., 2019). In Bengawan Solo, there are more than 30 dams that have different purposes. Most dams are built for irrigation purposes, while only a few for hydropower such as Gajah Mungkur dam in upstream area. Dam construction may have a benefit for society such as for hydropower (Talukdar and Pal, 2017), but negative environmental impacts (Schulz and Adams, 2019) cannot be negligible especially under mismanagement. Specifically, dam construction without good planning will lead to watershed damages including loss of biodiversity (Hughes, 2017), decline of watershed functions (Hughes, 2017; Jones and Bull, 2020), economic loss (Araújo et al., 2020), and environmental damage (Khodarahmi et al., 2018). Several environmental damages that often occur due to dam construction are an increased sedimentation, flooding, changes in water flow, and loss of endemic flora and fauna (Cochrane et al., 2017; Fearnside, 2016).

The negative impacts of dam construction are associated with an increase of watershed vulnerability. Many indices have been developed to asses watershed vulnerability such as the spatial water resource vulnerability index-SWRVI (Jun et al. 2011) and watershed vulnerability index-WVI (Chaves and Alipaz, 2007). The SWRVI index uses the data of projected temperature and rainfall to identify the influence of climate change to watershed condition. This approach calculated hydrological condition of flood, drought, and water quality. On other hand, the WSI mainly focused on policy response to hydrological dynamics in watershed scale (Chaves and Alipaz, 2007).

However, both indices were not design to assess and to quantify the impact of dam construction on watershed, which is focus of this study. In recent years, a new index called as dam environmental vulnerability index (DEVI) was proposed to assess the influence of dam construction on the watershed vulnerability (Latrubesse et al., 2017). DEVI was initially developed in Amazon basin, which used information of land use, rainfall, soil type, location of dam, and water stage as the input for analysis.

There are three indices used to calculation of vulnerability using DEVI method (Latrubesse et al., 2017), namely basin integrity index (BII), fluvial dynamics index (FDI), and dam impact index (DII). BII represents the watershed vulnerability due to erosion and runoff. On other hand, FDI and DII explain the vulnerability of watershed that is influenced by morpho-dynamics activity and dam location. DEVI was scaled from 0-100, which indicates the higher the value, the more the vulnerability is. Application of DEVI is pro- mising for other regions than Amazon as many dams have been built in many countries including in China (Tang et al., 2018), Myanmar (Kirchherr et al., 2017), Malaysia (Lee et al., 2018), and Indonesia (Somura et al., 2019). Here we tried to implement DEVI approach in Indonesia with specific objectives to (i) calculate the vulnerability of Bengawan Solo watershed and (ii) analyze the dominant variable that influences the vulnerability.

\section{RESEARCH METHODS}

\section{Study Area and Data}

The research area of this study was Bengawan Solo watershed, which consists of five sub-watersheds namely Babat, Cepu, Madiun, Jurug, and Wonogiri as presented in Figure 1. Most of upstream area was categorized as very steep (slope $>40 \%$ ) especially in the highland of Mount of Lawu and Mount of Merapi. The flat slope is found in downstream area (slope 0-8\%). Based on land use analysis in 2018 (Ministry of Environment and Forestry, 2018), rice field predominantly covered the watershed by $30.25 \%$, followed by plantation (24.17\%), settlement (15.34\%), mixed dry land agriculture $(12.15 \%)$, and the rests for other purposes (10\%).

For DEVI calculation, several data were collected i.e. (i) topographic data based on digital elevation model (DEM) from USGS (resolution 30m); (ii) land use for 2018 (scale 1:250,000) available online through http://webgis.menlhk.go.id/; (iii) channel width for 2013 and 2019 (based on Landsat 8 images) available online from Google Earth Pro; (iv) daily discharge data from five observation stations in Babat (1971-2013), Cepu (1972-2006), Jurug (1975-2016), Madiun (1975-2013), and Wonogiri (2003-2013); and (v) the number of dams in each sub-watersheds.

To obtain watershed boundary, DEM data was processed in GIS platform (ArcGIS 10.4 software). From this process, information on area each sub-watershed was derived. Land use analysis for DEVI calculation also was perform in GIS platform. For channel width, we chose 2013 and 2019 as both years represented the longer period observation of Landsat 8. Daily discharge data was used to obtain mean water stage variability for each sub-watershed. Statistical and sensitivity analysis for this study were performed in R statistical language (R Core Team, 2020) with IDE RStudio Version 1.1.453.

\section{Dam Environmental Vulnerability Index (DEVI)}

DEVI consists of three sub-indices namely (i) basin integrity index (BII), (ii) fluvial dynamics index (FDI), and (iii) dam impact index (DII). The BII depends on deforested and protected area. FDI was influenced 


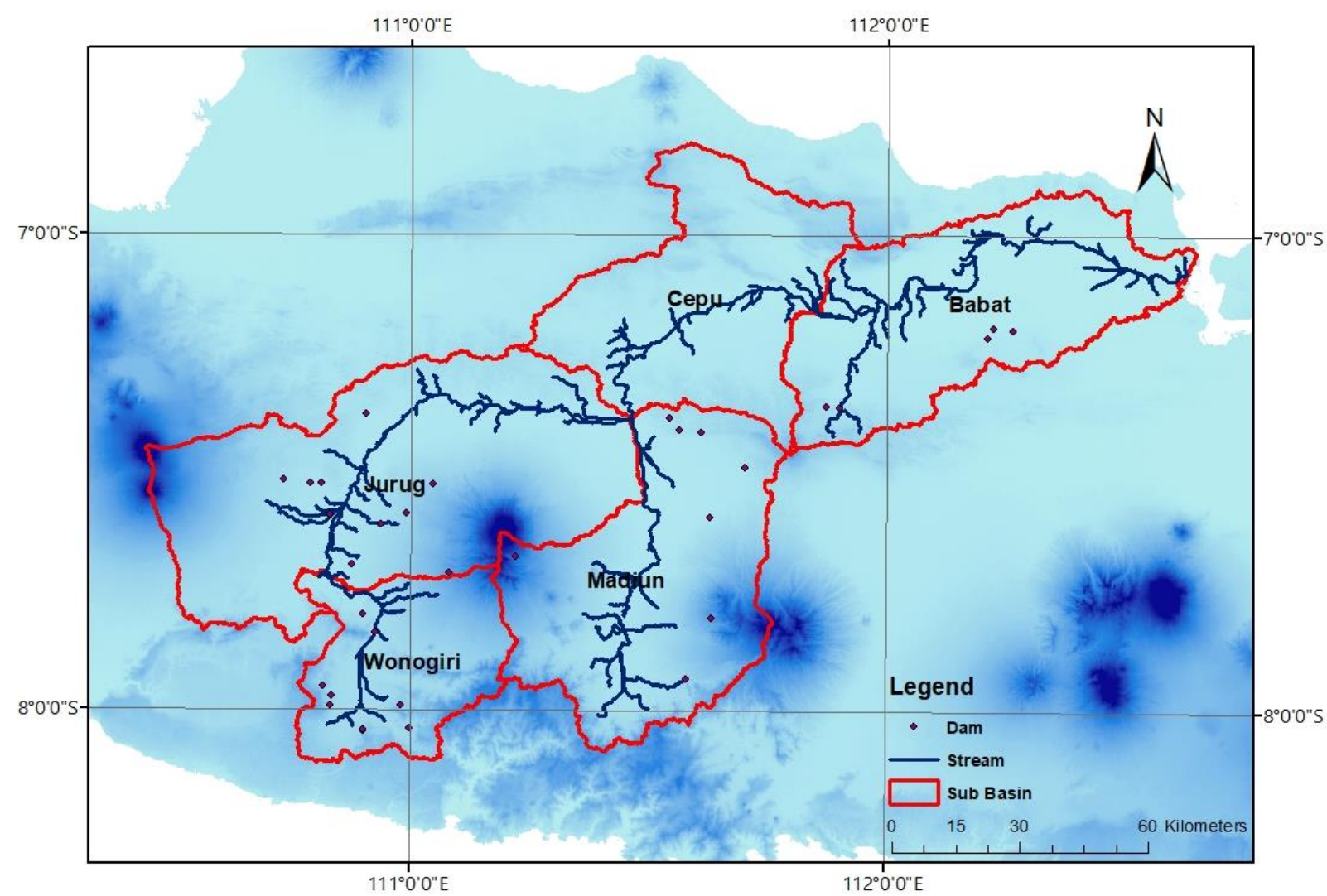

Figure 1. Location of study area in Bengawan Solo watershed in Java Island. A red line indicates watershed boundary, a blue line indicates river network, and dot brown shows dam location.

Table 1. List of variables used to calculate dam environmental vulnerability index (DEVI)

\begin{tabular}{|c|c|c|c|c|c|c|c|}
\hline No & Variable & Symbol & Unit & No & Variable & Symbol & Unit \\
\hline \multicolumn{4}{|c|}{ Basin Integrity Index } & \multicolumn{4}{|c|}{ Fluvial Dynamics Index } \\
\hline 1. & $\begin{array}{l}\text { Percent of the basin that is } \\
\text { presently deforested }\end{array}$ & PBD & - & 9. & $\begin{array}{l}\text { Average channel } \\
\text { migration rates }\end{array}$ & MR & $\mathrm{m}$ \\
\hline 2. & Normalized PBD & NPBD & - & 10. & Normalized MR & NMR & \\
\hline 3. & $\begin{array}{l}\text { Percent of the basin under } \\
\text { protected area }\end{array}$ & PBP & - & 11. & & A & $\mathrm{km}^{2}$ \\
\hline 4. & Normalized PBP & NPBP & - & 12. & Sediment yield & SY & ton $\mathrm{km}^{-2}$ year-1 $^{-1}$ \\
\hline 5. & $\begin{array}{l}\text { Percent of the basin that is } \\
\text { deforested but located upstream } \\
\text { of the farthest downstream dam }\end{array}$ & PUD & - & 13. & Normalized SY & NSY & - \\
\hline 6. & Normalized PUD & NPUD & - & 14. & $\begin{array}{l}\text { Mean water } \\
\text { stage variability }\end{array}$ & WSV & $\mathrm{m}$ \\
\hline 7. & $\begin{array}{l}\text { Percent of the protected area } \\
\text { upstream of the farthest } \\
\text { downstream dam }\end{array}$ & PUP & - & 15. & $\begin{array}{l}\text { Normalized } \\
\text { WSV }\end{array}$ & NWSV & - \\
\hline 8. & Normalized PUP & NPUP & - & & & & \\
\hline \multicolumn{4}{|c|}{ Dam Impact Index } & & & & \\
\hline 16. & $\begin{array}{l}\text { A ratio of river length directly } \\
\text { affected by dams }\end{array}$ & PLU & - & & & & \\
\hline 17. & $\begin{array}{l}\text { A ratio between the number of } \\
\text { major tributaries with dams and } \\
\text { the total number of major } \\
\text { tributaries }\end{array}$ & PTA & - & & & & \\
\hline 18. & $\begin{array}{l}\text { Number of dams (planned and } \\
\text { existing) per basin }\end{array}$ & PNU & - & & & & \\
\hline
\end{tabular}


by river morpho-dynamics activity, sediment transport, and river water stage, whereas DII is calculated from characteristic of river channel and dam.

\section{Basin Integrity Index (BII)}

Basin integrity index (BII) shows the vulnerability of sub-watersheds due to erosion and runoff, which can be indicated from forest and non-forest land cover. BII is influenced by four variables namely: (i) percent of basin deforested (PBD), (ii) percent of basin under protected area (PBP), (iii) percent of upstream deforested (PUD), and (iv) percent of upstream under protected area (PUP). There were three steps to calculate BII in Bengawan Solo, as follow: (i) calculating the area of the Bengawan Solo sub-watershed; (ii) identifying and calculating the forest (protected area) and non-forest land covers to derive PBD, PBP, PUD, and PUP; and (iii) calculating the BII based on Equation (1-5) (Latrubesse et al., 2017).

$$
\begin{aligned}
& N P B D i=\frac{[P B D i-\min (P B D)]}{[\max (P B D)-\min (P B D)]} \\
& N P B P i=\frac{[P B P i-\max (P B P)]}{[(\min (P B P)-\max (P B P)]} \\
& N P U D i=\frac{[P U D i-\min (P U D)]}{[\max (P U D)-\min (P U D)]} \\
& N P U P i=\frac{[P U P i-\max (P U P)]}{[\min (P U P)-\max (P U P)]} \\
& B I I i=\frac{100 x(N P B D i+N P B P i+N P U D i+N P U P i)}{4}
\end{aligned}
$$

Explanation on variables used in Equation (1-5) is referred to Table 1. PBD and PBP show the effect of size of sub-watershed. On other hand, PUP and PUD indicate the effect of the farthest downstream dam related to the main channel. If the sub-watershed does not have any dam like in Cepu sub-watershed, the value of PUP and PUD is 0. BII value ranges from 0-100, which indicates the higher BII value, the bigger sub-watershed vulnerability (Latrubesse et al., 2017).

\section{Fluvial Dynamics Index (FDI)}

There are three variables that control FDI, namely sediment yield (SY), migration rate (MR), and water stage variability (WSV). In this research, SY was referred to Hannum (2020) with its value ranged of $0.24-0.68$ Mton $\mathrm{km}^{-2}$ year-1. MR indicates the absolute difference of channel width between 2019 and 2013. WSV was calculated based on the daily average of river water stage in observation station for each sub-watershed. Further, FDI was calculated based on Equation (6-9).

$$
N S Y i=\frac{[S Y i-\min (S Y)]}{[\max (S Y)-\min (S Y)]}
$$

$$
\begin{aligned}
& N M R i=\frac{[M R i-\min (M R)]}{[\max (M R)-\min (M R)]} \\
& N W S V i=\frac{[W S V i-\min (W S V)]}{[\max (W S V)-\min (W S V)]} \\
& F D I i=\frac{100 x(N S Y i+N M R i+N W S V i)}{3}
\end{aligned}
$$

FDI value ranges from 0-100. The higher FDI, the bigger vulnerability of sub-watershed (Latrubesse et al., 2017).

\section{Dam Impact Index (DII)}

Dam impact index (DII) shows the influence of dam to river system. DII was obtained by calculating (i) ratio of river length directly affected by dams (PLU); (ii) ratio between the number of major tributaries with dams and the total number of tributaries (PTA); and (iii) number of existing dams per sub-watershed (PNU). Detail explanation for each calculation, the readers may refer to Latrubesse et al. (2017). For PTA calculation, we modified the size of tributary i.e. $1 \%$, instead $10 \%$ in the referred literature. DII was calculated using Equation 10.

$$
D I I i=\frac{100 x(P L U i+P T A i+P N U i)}{3}
$$

DII ranges from 0-100. The higher DII, the bigger vulnerability of sub-watershed (Latrubesse et al., 2017). The procedure of DEVI calculation is shown in Figure 2.

Then, the DEVI was computed by Equation (11). Calculation of DEVI assumed that the weight factor for each sub-index is equal. DEVI is numerical index ranging from $0-100 \%$, which is grouped in five classes (Table 2). The higher the value, the vulnerability of watershed rises.

$$
D E V I=(B I I+F D I+D I I) / 3
$$

Table 2. Vulnerability class of watershed based on DEVI values

\begin{tabular}{llc}
\hline No. & Class & Range (\%) \\
\hline 1. & Very low & $0-20$ \\
\hline 2. & Low & $20-40$ \\
\hline 3. & Moderate & $40-60$ \\
\hline 4. & High & $60-80$ \\
\hline 5. & Very high & $>80$ \\
\hline
\end{tabular}

\section{Sensitivity analysis}

To identify the dominant variable influencing DEVI, one procedure called as sensitivity analysis approach may apply. All of variables in Figure 2 were tested and simulated with this approach. The variables were separately changed from $-50 \%$ to $+50 \%$ with step of $25 \%$. The separate sensitivity means that one variable tested was as an independent variable, whereas other variables were constant. Based on this sensitivity, we compared the value of DEVI for each independent vari- 


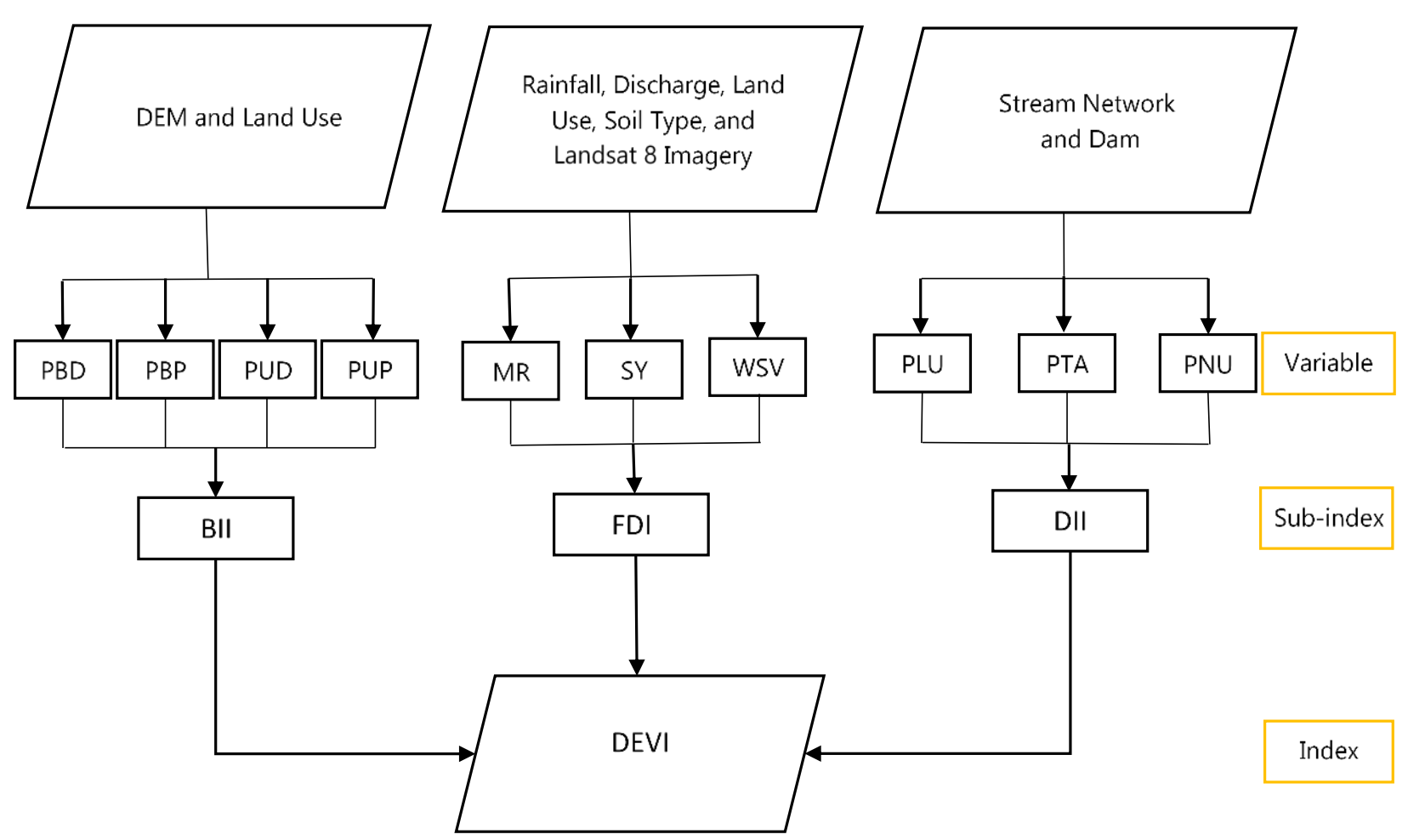

Figure 2. Flowchart diagram to derive dam environmental vulnerability index (DEVI). Explanation for each variable is presented in Table 1.

able. The most sensitive variable was represented by the highest DEVI value. We performed the sensitivity analysis for each sub-watershed.

\section{RESULTS AND DISCUSSIONS}

\section{Hydrological Characteristics of the Bengawan Solo}

The characteristic of hydrology can be described by the pattern of discharge. Distribution of discharge followed rainfall pattern, which was high discharge during rainy season (February-March) and low discharge in dry season (July-September). Figure (3) presents monthly discharge for each sub-watershed in Bengawan Solo. The magnitude of discharge depends on location of gauging station, where the upstream station will have lower discharge, and vice versa. For instance, Babat station that represents the downstream area has the highest monthly discharge $\left(472.7 \mathrm{~m}^{3} \mathrm{~s}^{-1}\right.$, ranges 137-964 $\mathrm{m}^{3} \mathrm{~s}^{-1}$ ), whereas Wonogiri station (upstream) has the lowest monthly discharge $\left(5.6 \mathrm{~m}^{3} \mathrm{~s}^{-1}\right.$, ranges $\left.0.3-15 \mathrm{~m}^{3} \mathrm{~s}^{-1}\right)$. For middle station such as in Madiun, the average discharge was $29.2 \mathrm{~m}^{3} \mathrm{~s}^{-1}$ (ranges 4-65 $\left.\mathrm{m}^{3} \mathrm{~s}^{-1}\right)$.

\section{Basin Integrity Index (BII)}

BII represents the influence of forest and nonforest cover. For Wonogiri sub-watershed, forest cover was relatively small $(\sim 5 \%)$, whereas the non-forest covers dominated the sub-watershed. This condition had caused high value of PBD and low PBP in the upstream Wonogiri sub-watershed. For the downstream
Babat, forest cover was relatively high that had caused high value of PBP (Table 3). The higher the PBD value, the vulnerability of watershed will increase. Our study suggested that the upstream watershed, represented by Wonogiri and Jurug, was the most vulnerable as high erosion and runoff due to deforestation. For the downstream and middle Bengawan Solo, large area of forest cover was able to decline the vulnerability of watershed due to the erosion process. Value of PBD varies from 0.68 (Babat) to 0.91 (Wonogiri). PBD in Cepu and Madiun were relatively closed to that of Babat. In contrast to PBD, the PBP value was smaller, which ranged from 0.05 (Wonogiri) to 0.29 in Madiun. The upstream Jurug had low PBP, whereas the middle (Madiun) and downstream had the higher PBP than the upstream.

Location of dam influenced the BII value by controlling PUD and PUP. The value of PUD and PUP was comparable to the value of PBD and PBP. For PUD, the upstream had the highest value (0.97), which means that almost the area was non-forest cover. A lower value of PUD was shown in the middle and downstream areas ( 0.7). The low PUD means that the deforestation in the sub-watershed was relatively not intensive. Overall, the value of PUD ranged from 0.70 to 0.97 . The findings suggested that intensive deforestation implies to higher PUD value. For PUP, its value was relatively small ranging from 0.03-0.29. In upstream subwatershed, PUP was very small $(0.03$, Table 3$)$ that indicated a low protected area. In the downstream area, 

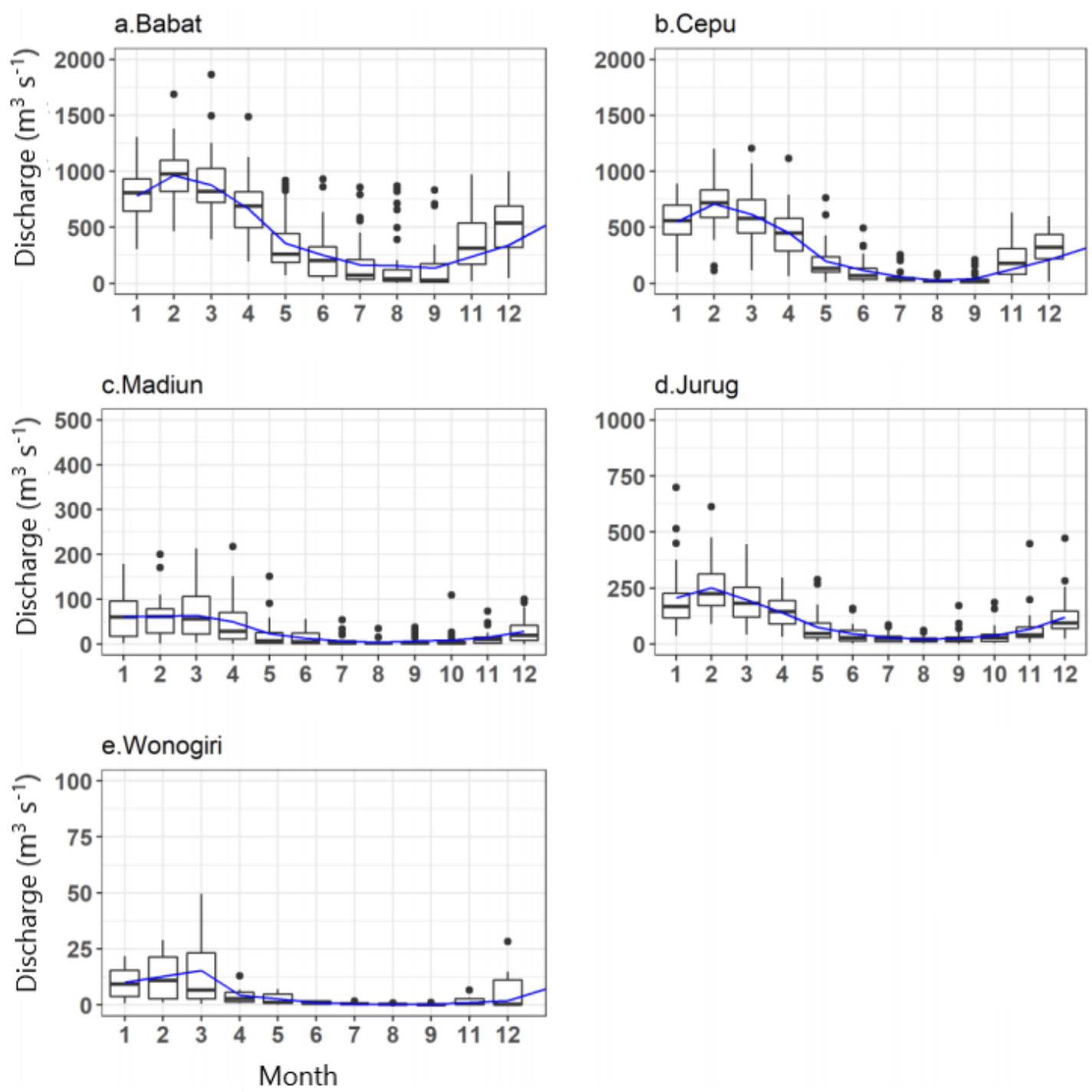

Figure 3. Summary statistics (box: 25, 50 and 75 deciles, whiskers: 5 and 95 deciles) of the average of monthly discharge for each sub-watershed in Bengawan Solo.

the PUP was high (0.27) that was able to show the highly proportion of protected forest. The value of PBD, PBP, PUD, and PUP was normalized for each subwatershed. The normalized value then was used to calculate BII. For the sub-watershed with a high deforestation, the BII value was high as well due to high contribution from the PBD and PUD. For example, in Wonogiri sub-watershed the value of PBD and PUD was the highest (0.91 and 0.97, respectively) that contributed to the highest BII $(100 \%$, Table 3$)$. On the other hand, in the high protected area such as in Madiun the BII was the lowest (73\%).

\section{Fluvial Dynamics Index (FDI)}

FDI was determined by channel width, sediment rate, and water stage. The influence of channel width associated with the position of river within watersheds. Topographically, more upstream the position of river, the channel width is narrower. Therefore, sub-watershed in the downstream area has a wide channel. For instance, based on sampling of 31 cross-sections in Babat sub-watershed, the channel width in Babat was $23.6 \mathrm{~m}$. On other hand, in the upstream Wonogiri, the channel width was $6.25 \mathrm{~m}$ (28 cross-sections). The lowest channel width was observed in Madiun subwatershed, which was $5.46 \mathrm{~m}$ (13\% lower than Wonogiri sub-watershed). Another sub-watershed had an average channel width of $8.99 \mathrm{~m}$ and $13.21 \mathrm{~m}$ for Jurug and Cepu sub-watershed, respectively. Sedimentation rate ranged from 0.24-0.68 Mton $\mathrm{km}^{2}$ year-1 (Hannum, 2020), with the lowest value in Wonogiri sub-watershed

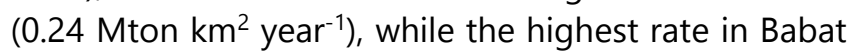
(Table 3).

The third variable that controls FDI was average daily water stage in each sub-watershed. Location in upstream will have low water stage, while downstream shows high water stage. Based on observation data in Babat, the water stage was $4.23 \mathrm{~m}$, which was two times higher than in Cepu (2.13 m). In other sub-watersheds, the water stage were $2.94 \mathrm{~m}$ and $2.56 \mathrm{~m}$ for Madiun and 
Table 3. Variation of BII value in each sub-watershed, which describes the ratio of forest and non-forest cover to the area of each sub-watershed

\begin{tabular}{lccccc}
\hline Variable & Babat & Cepu & Madiun & Jurug & Wonogiri \\
\hline Basin Integrity Index & & & & & \\
\hline PBD & 0.68 & 0.73 & 0.7 & 0.85 & 0.91 \\
\hline PBP & 0.25 & 0.27 & 0.29 & 0.13 & 0.05 \\
\hline PUD & 0.71 & 0.73 & 0.7 & 0.97 & 0.97 \\
\hline PUP & 0.27 & 0.27 & 0.29 & 0.03 & 0.03 \\
\hline BII (\%) & $\mathbf{7 4}$ & $\mathbf{7 6}$ & $\mathbf{7 3}$ & $\mathbf{9 6}$ & $\mathbf{1 0 0}$ \\
\hline Fluvial Dynamics Index & & & & & \\
\hline MR (m) & 23.6 & 13.2 & 5.4 & 8.9 & 6.2 \\
\hline SY (Mton km $^{-2}$ year $^{-1}$ ) & 0.68 & 0.65 & 0.57 & 0.63 & 0.24 \\
\hline WSV (m) & 4.2 & 2.1 & 2.9 & 2.6 & 1.6 \\
\hline FDI (\%) & $\mathbf{1 0 0}$ & $\mathbf{5 8}$ & $\mathbf{4 7}$ & $\mathbf{5 3}$ & $\mathbf{1 5}$ \\
\hline Dam Impact Index & & & & & \\
\hline PLU & 0.18 & 0.17 & 0.17 & 0.02 & 0.1 \\
\hline PTA & 0.4 & 0.41 & 0.65 & 0.32 & 0.5 \\
\hline PNU & 1 & 0.91 & 0.29 & 0.59 & 0.24 \\
\hline DII (\%) & $\mathbf{5 3}$ & $\mathbf{5 0}$ & $\mathbf{3 7}$ & $\mathbf{3 1}$ & $\mathbf{2 8}$ \\
\hline DEVI (\%) & $\mathbf{7 6}$ & $\mathbf{6 1}$ & $\mathbf{5 2}$ & $\mathbf{6 0}$ & $\mathbf{4 8}$ \\
\hline NOte: PBD and PBP & & & & & \\
\hline
\end{tabular}

Note: PBD and PBP showed the non-forest and forest cover area in subwatershed, while PUD and PUP showed the non-forest and forest cover area in upstream of the farthest downstream dam. BII was calculated based on the average of normalized PBD, PBP, PUD, and PUP.

Jurug, respectively. The lowest water stage $(1.63 \mathrm{~m})$ was observed in Wonogiri sub-watershed that located in the upstream of Bengawan Solo.

FDI was calculated from the average normalized of MR, SY, and WSV. The value of FDI ranged from 15100 , which meant 100 was the most vulnerable. The high FDI indicated that the sub-watershed was very dynamics due to river morpho-dynamic activity. In Babat, the FDI was maximum due to highest migration rate (MR), highest sediment yield (SY), and highest water stage (WSV) compared to other sub-watersheds. High sediment yield in Babat was the accumulation of sediment from upstream and midstream of watershed that flow to downstream Babat. In contrast, Wonogiri had the lowest FDI as lowest sediment yield and water stage (Table 3). Other sub-watersheds in Cepu, Jurug, and Madiun had a comparable FDI value $(\sim 50)$ due to relatively equal value of sediment yield.

\section{Dam Impact Index (DII)}

DII was sub-index that represented influence of dam existence including under construction dam. However, we only focused on the impact of existing dam to the vulnerability of sub-watershed due to the lack of data of the planned dam construction. DII was influenced by river length affected by dams, number of tributaries affected by dams, and number of existing dams within sub-watershed.

\section{Ratio of River Length Directly Affected by Dams (PLU)}

The dam location influences the size of the impacted area within sub-watershed such as the length of river that was affected by dam. If the location of dam is more downstream, the length of river affected by the dam is increasing. The PLU value ranged from 0.02-0.18 (Table 3). For instance, in Madiun sub watershed the river length affected by dam was $24.82 \mathrm{~km}$ that was equivalent to PLU of 0.17 (Table 3). The extreme condition was found in the downstream, Babat subwatershed, in which river length affected by dams was $116.29 \mathrm{~km}$ or equivalent with PLU (0.18). In Cepu there is no big dam for hydropower, therefore we assumed that the PLU value was similar to that of Madiun.

\section{Number of Major Tributaries Affected by Dams (PTA)}

The area of tributaries related to dam location influences the vulnerability of watershed. Based on DEVI method, the smallest tributary area was chosen to determine the PTA. This research applied tributary area of $1 \%(1,500 \mathrm{ha})$ as the threshold resulting 119 tributaries throughout Bengawan Solo watershed. Most 
of tributaries were found in the downstream Babat and Cepu (48 and 39). In the upstream only 5 tributaries were identified in Wonogiri. Overall, PTA value ranged from 0.32-0.65.

\section{Number of Dams per Basin (PNU)}

Number of dams in a sub-watershed influenced on watershed vulnerability. The greater the number of dams, the more vulnerable the watershed is. Based on the observed data, the low number of dams was identified in Wonogiri and Madiun sub-watershed, namely 8 and 10 dams, respectively. On other hand, Jurug and Cepu sub-watershed had 20 and 31 dams. Babat sub-watershed had the highest number of dams i.e. 34 dams. A ratio between number of dams in a subwatershed with total number of dams in Bengawan Solo watershed was called as PNU. The value of PNU from the highest to the lowest was: 1 (Babat); 0.91 (Cepu); 0.59 (Jurug); 0.29 (Madiun); and 0.24 (Wonogiri).

DII ranged from 28-53 with high vulnerability occurred in Babat sub-watershed, while low vulnerability in Wonogiri sub-watershed. High vulnerability of the index strongly correlated to the number of dams within each sub-watershed. In downstream Babat, the number of dams is the largest resulting highest DII. In contrast, Wonogiri (upstream) had the smallest dams that contributed to the lowest DII (Table 3).

\section{Dam Environmental Vulnerability Index (DEVI)}

DEVI ranged from 48-76\% (Table 3) with the highest value in Babat sub-watershed, while the lowest in Wonogiri sub-watershed. On average, the level of vulnerability for Bengawan Solo watershed was categorized as highly vulnerable (DEVI $=60 \%$ ). Babat and Cepu sub-watersheds contributed to the high DEVI as both were in high class ( $76 \%$ and $61 \%$, respectively). Morpho-dynamic activities were very intensive in both Babat and Cepu as indicated by high sediment yield and water stage (Table 3, FDI). In addition, river system affected by dams was the most in Babat (Table 3, DII).

A combination of high FDI and DII had caused high DEVI in Bengawan Solo. In contrast, Wonogiri and Madiun had the lowest DEVI as supported by low FDI and DII. Although deforestation in Wonogiri was intensive that contributed to the highest BII (100), but it only contributed to one-third of DEVI computation. Here, the findings showed that morpho-dynamics activites and number of dams were more important than deforestation to asses DEVI.

\section{Sensitivity Analysis}

Sensitivity analysis was used to identify the most influenced variables of DEVI. In this research, we identified ten variables affecting DEVI as presented in Table 3. We expected that sensitivity for each variable was different due to variability in physical properties of each sub-watershed. In addition, morpho-dynamics activities in each sub-watershed were distinct such as sediment rate and water stage dynamics. Figure 4 presents the sensitivity for each variable. The influence of variable to DEVI was indicated by the percent change of DEVI (y-axis, Figure 4). The most influence variable was shown by the largest percent change as indicated by the steepness line of the graphic.

For BII variables (PBD, PBP, PUD, and PUP), the sensitivity showed that changes of DEVI value were about $\pm 15 \%$ when we applied change in the variable up to $\pm 50 \%$. This result was consistent for all subwatershed. Likely deforested area was the most sensitive variable for BII. For FDI, the results of sensitivity varied among sub-watershed. In Babat sub-watershed, all of FDI variables had equal sensitivity. Changes in the variable value up to $\pm 50 \%$ only resulted in sensitivity in DEVI by $\pm 20 \%$. More upstream the sub-watershed, an increase of percent change in the sensitivity of DEVI was expected (Figure 4). For example, in Wonogiri subwatershed, only $25 \%$ change in the variable value was similar to $50 \%$ change in the variable value in Babat, which produced $\pm 20 \%$ change in the DEVI. Water stage and sediment yield were dominant to influence on DEVI value. For DII variables, the sensitivity value was fairly uniform $( \pm 30 \%)$ for the change in the variable value up to $\pm 50 \%$. The result was consistent for all subwatershed. The most sensitive variable was number of dams that was observed in Babat, Cepu, and Jurug subwatershed. On other hand, the ratio of tributaries was the most sensitive for Jurug and Wonogiri sub-watershed.

Overall, FDI was the most sensitive sub-index that influenced DEVI, especially for sediment yield variable. Otherwise, the least sensitive sub-index was BII as represented by its variable. The DII sub-index generated the moderate sensitivity. Number of dams and ratio of tributaries were dominant variable influencing DEVI. The high sensitivity means that the small change of variable will result large change of the DEVI value, and vice versa.

This study is the first research in Indonesia that utilizes physical properties of watershed to examine the impact of dam construction to the vulnerability of watershed. Although there were several approaches to asses vulnerability (e.g. Chaves and Alipaz, 2007; Jun et al., 2011), the available approaches were not specially develop for dam assessment impact on vulnerability. Here we applied DEVI method with some modification on the computation of tributaries ratio for each subwatershed. Generally, we followed the procedure that carried out by Latrubesse et al. (2017) with the case study in Amazon, in which the method may need some improvements. Further research is expected to analyze 

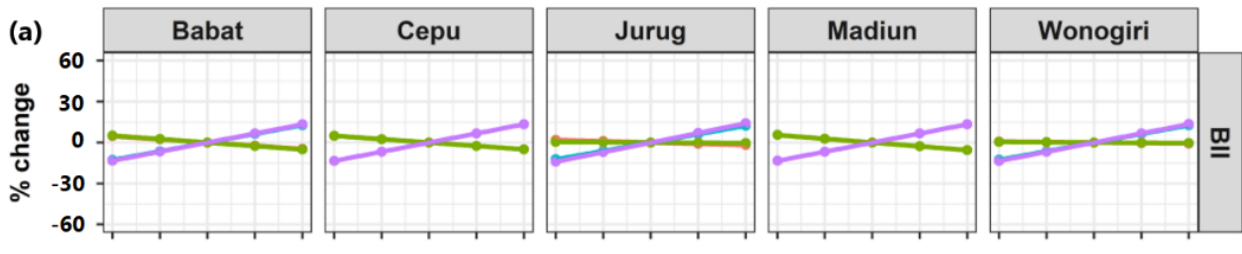

Protected area located in the upstream of the farthest downstream dam Deforested area

Deforested area located in the upstream of the farthest downstream dam
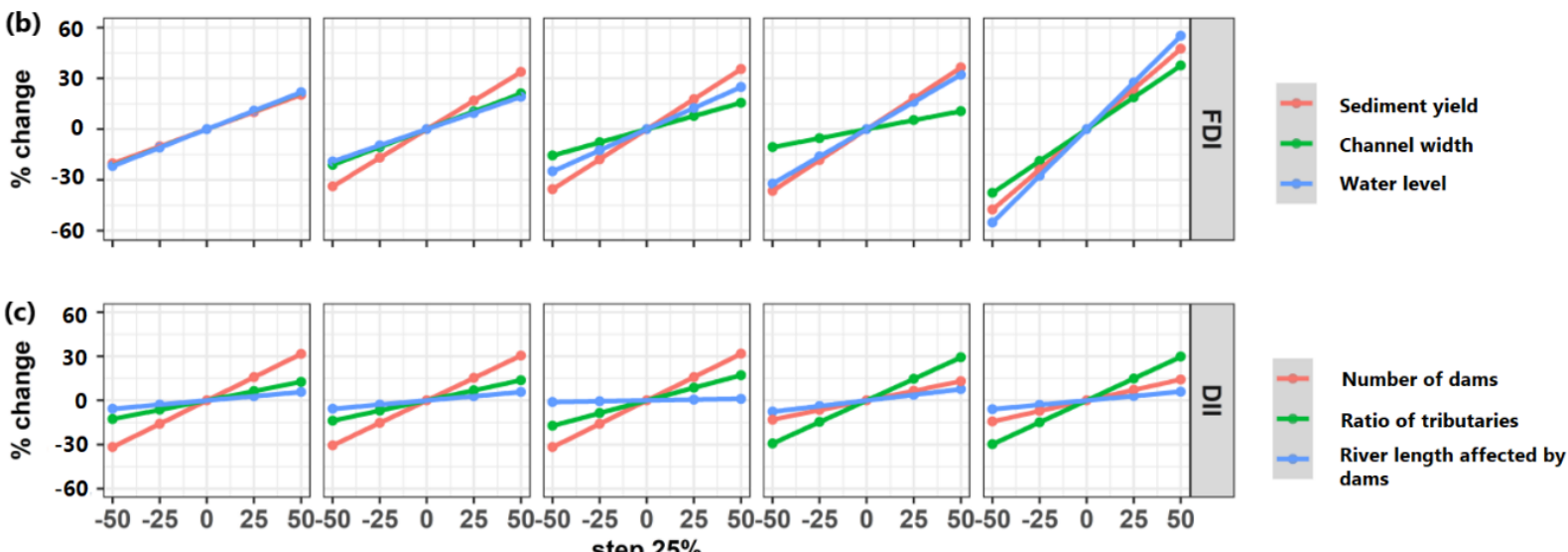

Figure 4. Sensitivity of DEVI variables in Bengawan Solo for each sub-watershed (top panel). Graph (a) provides the influence of basin integrity index (BII) on DEVI. Graph (b) gives the change of DEVI value in response to changes in the variables of fluvial dynamics index (FDI). Graph (c) shows the influence of dam impact index (DII) on DEVI value.

the effect of irrigation dams on watershed vulnerability. DEVI method uses a conservation approach that takes into account the sustainability of an undisturbed ecosystem. However, other approaches that consider benefit of dams to society (Schmitt et al., 2019) should be into account for integrated water management.

Our findings revealed that vulnerability of the watershed was categorized as highly vulnerable. However, this high vulnerability did not spread everywhere in sub-watershed. For example, Madiun and Wonogiri sub-watershed was categorized as moderate vulnerable (52\% and $48 \%$ ). This result is consistent with the condition of Bengawan Solo that is categorized as one of critical watersheds in Indonesia. High deforestation that contributes to severe erosion and sediment rate has caused high vulnerability of the watershed. However, our result showed that dam construction was less important on the vulnerability (Table 3, DII). Further, more researches are expected to adjust DEVI application on other regions than Amazon. In Indonesia, irrigation dams that not for hydropower are common, in which their existence need to be accommodated in DEVI approach. Also, the equal proportion of each subindex in calculating DEVI may need adjustment for better result.

\section{CONCLUSSIONS}

This research applied DEVI for assessing vulnerability of Bengawan Solo watershed in response to dam construction in the watershed. Based on our analysis, the vulnerability of the watershed was medium to high level (60\%). High vulnerability was found in downstream (Babat and Cepu sub-watersheds), while the moderate vulnerability was in upstream (Madiun and Wonogiri). The findings revealed that sediment rate was the most influence variable controlling DEVI, as shown by the result of sensitivity analysis. Other variables influencing DEVI the most were water stage and channel width. For better application in other regions than Amazon, the DEVI method needs some adjustment to appropriately assess dam construction impact on environment.

\section{ACKNOWLEDGEMENTS}

The authors thank to Center for Water Resources, Ministry of Public Works Government of Indonesia for providing daily discharge data. Also, the authors thank to Melda Hazrina for her kindly assistance in calculating DEVI.

\section{REFERENCES}

Araújo, J.G. de, Santos, M.A.S. dos, Rebello, F.K., Prang, G., Almeida, M.C. de, Isaac, V.J., 2020. Economic analysis of the threats posed to the harvesting of ornamental fish by the operation of the Belo Monte hydroelectric dam in northern Brazil. Fisheries Research 225, 105483. https://doi.org/10.1016/j.fishres.2019.105483 
Chaves, H.M.L., Alipaz, S., 2007. An Integrated Indicator Based on Basin Hydrology, Environment, Life, and Policy: The Watershed Sustainability Index. Water Resour Manage 21, 883-895. https://doi.org/10.1007/s11269-006-9107-2

Cochrane, S.M.V., Matricardi, E.A.T., Numata, I., Lefebvre, P.A., 2017. Landsat-based analysis of mega dam flooding impacts in the Amazon compared to associated environmental impact assessments: Upper Madeira River example 2006-2015. Remote Sensing Applications: Society and Environment 7, 1-8. https://doi.org/10.1016/j.rsase.2017.04.005

Dasanto, B., 2006. Evaluasi Dampak Perubahan Penggunaan Lahan terhadap Volume Limpasan Studi Kasus: DAS Ciliwung Hulu, Jawa Barat (Evaluation Of Landuse Change Impact On Run-off Volume Case Study: Ciliwung Hulu Watershed, West Java). Agromet 20.

Fearnside, P.M., 2016. Environmental and Social Impacts of Hydroelectric Dams in Brazilian Amazonia: Implications for the Aluminum Industry. World Development 77, 48-65. https://doi.org/10.1016/j.worlddev.2015.08.01 5

Hannum, M., 2020. Kerentanan DAS Bengawan Solo Menggunakan Metode Dam Environmental Vulnerability Index (DEVI). IPB University, Bogor

Hidayat, F., Juwono, P.T., Suharyanto, A., Pujiraharjo, A., Legono, D., Sisinggih, D., Neil, D., 2018. Study of reservoir sedimentation due to volcanic eruption and its management. Dams and Reservoirs 28, 73-81. https://doi.org/10.1680/jdare.18.00005

Hughes, A.C., 2017. Understanding the drivers of Southeast Asian biodiversity loss. Ecosphere 8, e01624. https://doi.org/10.1002/ecs2.1624

Irsyad, F., Saptomo, S.K., Setiawan, B.I., 2011. ANALISIS PERUBAHAN IKLIM LOKAL DAN DEBIT SUNGAI DI DAS CIDANAU ANALYSIS OF LOCAL CLIMATE CHANGE AND DISCHARGE IN CIDANAU WATERSHED. Agromet 25, 17-23.

Jones, I.L., Bull, J.W., 2020. Major dams and the challenge of achieving "No Net Loss" of biodiversity in the tropics. Sustainable Development 28, 435-443. https://doi.org/10.1002/sd.1997

Jun, K.S., Chung, E.-S., Sung, J.-Y., Lee, K.S., 2011. Development of spatial water resources vulnerability index considering climate change impacts. Science of The Total Environment 409, 5228-5242. https://doi.org/10.1016/j.scitotenv.2011.08.02 7
Khodarahmi, M., Amiri, M.J., Karbassi, A., Tajziehchi, S., Darabi, H., 2018. Assessment and Estimation of Environmental Costs of Kasilian Dam. Asian Journal of Water, Environment and Pollution 15, 107-114. https://doi.org/10.3233/AJW-180023

Kirchherr, J., Charles, K.J., Walton, M.J., 2017. The interplay of activists and dam developers: the case of Myanmar's mega-dams. International Journal of Water Resources Development 33, 111-131. https://doi.org/10.1080/07900627.2016.11791 76

Latrubesse, E.M., Arima, E.Y., Dunne, T., Park, E., Baker, V.R., d'Horta, F.M., Wight, C., Wittmann, F., Zuanon, J., Baker, P.A., 2017. Damming the rivers of the Amazon basin. Nature 546, 363369.

Lee, K.E., Shahabudin, S.M., Mokhtar, M., Choy, Y.K., Goh, T.L., Simon, N., 2018. Sustainable water resources management and potential development of multi-purpose dam: the case of Malaysia. Applied Ecology and Environmental Research 16, 2323-2347.

Li, C., Sun, G., Caldwell, P.V., Cohen, E., Fang, Y., Zhang, Y., Oudin, L., Sanchez, G.M., Meentemeyer, R.K., 2020. Impacts of Urbanization on Watershed Water Balances Across the Conterminous United States. Water Resources Research 56, e2019WR026574. https://doi.org/10.1029/2019WR026574

Marhaento, H., Booij, M.J., Rientjes, T.H.M., Hoekstra, A.Y., 2017. Attribution of changes in the water balance of a tropical catchment to land use change using the SWAT model. Hydrological Processes 31, 2029-2040. https://doi.org/10.1002/hyp.11167

Maulana, M.A., Satrya, T.R., Soemitro, R.A.A., Warnana, D.D., Mukunoki, T., 2019. Suspended sediment distribution corresponds to erosion and deposition processes at Bengawan Solo River, Indonesia. Presented at the Third International Conference on Sustainable Innovation 2019 Technology and Engineering (ICOSITE 2019), Atlantis Press, pp. 49-52. https://doi.org/10.2991/icosite-19.2019.10

Ministry of Forestry, 2009. Penetapan Daerah Aliran Sungai (DAS) Prioritas dalam Rangka Rencana Pembangunan Jangka Menengah (RPJM) Tahun 2010-2014.

Naz, S., Ahsanuddin, M., Inayatullah, S., Siddiqi, T.A., Imtiaz, M., 2019. Copula-Based Bivariate Flood Risk Assessment on Tarbela Dam, Pakistan. Hydrology 6, 79. 
R Core Team, 2020. R: A Language and Environment for Statistical Computing. $\mathrm{R}$ Foundation for Statistical Computing, Vienna, Austria.

Schmitt, R.J.P., Bizzi, S., Castelletti, A., Opperman, J.J., Kondolf, G.M., 2019. Planning dam portfolios for low sediment trapping shows limits for sustainable hydropower in the Mekong. Science Advances 5, eaaw2175. https://doi.org/10.1126/sciadv.aaw2175

Schulz, C., Adams, W.M., 2019. Debating dams: The World Commission on Dams 20 years on WIREs Water 6, e1396. https://doi.org/10.1002/wat2.1369

Soemitro, R.A.A., Adriati, F., Warnana, D.D., Mukunoki, T., Soetanto, R., Maulana, M.A., 2020. Sediment consolidation in ephemeral river: the effect of applied loading on soil properties and dredging method selection. International Journal of River Basin Management 0, 1-10. https://doi.org/10.1080/15715124.2020.17421 35

Somura, H., Yuwono, S.B., Ismono, H., Arifin, B., Fitriani, F., Kada, R., 2019. Relationship between water quality variations and land use in the Batutegi Dam Watershed, Sekampung, Indonesia. Lakes \& Reservoirs: Science, Policy and Management for Sustainable Use 24, 93-101. https://doi.org/10.1111//re.12221

Talukdar, S., Pal, S., 2017. Impact of dam on inundation regime of flood plain wetland of punarbhaba river basin of barind tract of Indo-Bangladesh. International Soil and Water Conservation Research 5, 109-121. https://doi.org/10.1016/j.iswcr.2017.05.003

Tang, Q., Collins, A.L., Wen, A., He, X., Bao, Y., Yan, D., Long, Y., Zhang, Y., 2018. Particle size differentiation explains flow regulation controls on sediment sorting in the water-level fluctuation zone of the Three Gorges Reservoir, China. Science of The Total Environment 633, 1114-1125. https://doi.org/10.1016/j.scitotenv.2018.03.25 8

Weil, K.K., Cronan, C.S., Lilieholm, R.J., Danielson, T.J., Tsomides, L., 2019. A statistical analysis of watershed spatial characteristics that affect stream responses to urbanization in Maine, USA. Applied Geography 105, 37-46.

Widyastuti, M.T., Taufik, M., 2019. Long-term Monthly Discharge Prediction for Cimanuk Watershed. Agromet 33, 96-104. https://doi.org/10.29244/j.agromet.33.2.96104

Wijayanti, R., Baiquni, M., Harini, R., 2016. Strategi penghidupan berkelanjutan masyarakat berbasis aset di Sub DAS Pusur, DAS Bengawan Solo. Jurnal Wilayah dan Lingkungan 4, 133152. 